\title{
ハンドヘルドダイナモメーターを用いた 下腿三頭筋筋力測定
}

\section{Measurement of Muscle Strength of Triceps Surae with a Hand-Held Dynamometer}

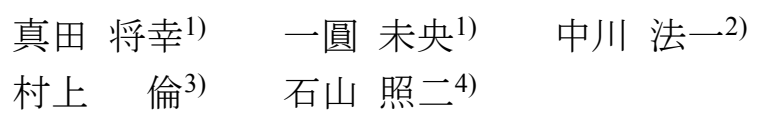

\author{
MASAYUKi SANADA, RPT ${ }^{1)}$, Mio ITIEN, RPT ${ }^{1)}$, NoRIKAZU NAKAGAWA, RPT, $\mathrm{PhD}^{2)}$, \\ RIN MURAKAMI, PO ${ }^{3)}$, SYOUJI ISIYAMA, $\mathrm{MD}^{4)}$ \\ 1) Department of Rehabilitation, Suita Municipal Hospital: 2-13-20 Katayama, Suita-city, Osaka 564-0082, Japan. \\ TEL +81 6-6387-3311 \\ 2) Department of Physical Therapy, Kansai Medical College \\ 3) MT Brace \\ 4) Department of Orthopadeic Surgery, Suita Municipal Hospital
}

Rigakuryoho Kagaku 23(3): 391-394, 2008. Submitted Sep. 13, 2007. Accepted Jan. 16, 2008.

ABSTRACT: [Purpose] The purpose of this study was to examine the reliability of measurement of a fixed belt which was developed for the measurement of muscle strength of triceps surae with a Hand-Held Dynamometer (HHD). [Subjects] We studied 22 legs of 11 healthy adults for intra-rater reliability, and 20 legs of 10 healthy adults for inter-rater reliability. [Methods] The subjects put their hands posterolateraly in the long sitting position for the measurement of muscle strength of triceps surae. After sufficient practice, isometric foot plantar flexion exercise with the fixed belt was measured and we studied the reliability with the intra-class correlation coefficient (ICC). [Results] The intra-rater reliability was 0.924 (ICC) and the inter-rater reliability was 0.809 (ICC). [Conclusion] It is possible to make objective and reliable measurements which are suitable for clinical use by any measurer.

Key words: hand-held dynamometer, reliability, triceps surae

要旨：〔目的〕本研究は，ハンドヘルドダイナモメーター（HHD）を用いた下腿三頭筋筋力測定用の固定ベルトを開 発したので，測定の信頼性について調査することを目的とした。〔対象〕検者内信頼性の調查が健常成人11名22肢，検 者間信頼性の調査が健常成人 10 名 20 肢とした。〔方法〕下腿三頭筋筋力測定は, 長座位にて後側方に両手を着き, 十分 な練習後に固定ベルトを用いて等尺性足関節底屈運動を測定し, 級内相関係数 (ICC) を用い信頼性を検討した。〔結 果〕検者内信頼性がICCにて0.924, 検者間信頼性がICCにて0.809であった。〔結語〕臨床上の使用に耐えうる客観性・ 信頼性のある測定が，誰にでも実施可能であると考える。 キーワード：ハンドヘルドダイナモメーター，信頼性，下腿三頭筋

\footnotetext{
1)市立吹田市民病院リハビリテーション科：大阪府吹田市片山町2-13-20（テ564-0082） TEL 06-6387-3311

2) 関西医科専門学校 理学療法学科

3) MTブレース

4) 市立吹田市民病院 整形外科

受付日 2007年9月13日＼cjkstart受理日２008年1月16日
} 


\section{I.はじめに}

筋力測定は，理学療法の臨床場面において実施頻度 が非常に高い検査項目の一つである。一般に筋力測定 は, 徒手筋力検查, ハンドヘルドダイナモメーター (Hand Held Dynamometer ; HHD) や等速度性筋力測定機器を用 いた測定法が主流である。HHD は，安価で可搬性・簡 便性に優れ, 筋力を客観的に数值化することが可能であ る。また，HHDにおける測定の信頼性については，測 定法の問題で測定の信頼性がそしいという懸念は解消 されつつある1)。しかし，測定の信頼性を検討した大部 分の報告は，四肢大関節を対象としたものが主流であ り, 小関節における測定の信頼性についての検討は非常 に少ない。中でも足関節底屈は, 支点と作用点との距離 が短いために, 主動作筋である下腿三頭筋筋力が弱化し ていても，関節回転モーメントを徒手によって固定・抵 抗するには難がある。したがって, 足関節底屈筋力にお ける測定方法が確立していないのが現状である。HHD を用いた足関節底屈筋力測定の信頼性を検討した先行 研究では, 筋力水準が低い高齢者を対象にしたもの2)や,
ひらめ筋単独の影響が強い膝関節屈曲位での足関節底 屈筋力における検討 3 ) をしており，ひらめ筋・腓腹筋 （下腿三頭筋）について検討した報告は少ない。筋力水 準が高いと思われる青年健常者の下腿三頭筋について 調査した報告4) もあるが，平均筋力值が $46.0 \mathrm{~kg}$ と全体重 を支え踵上げ動作（Heel Rise）を行い得る下腿三頭筋の 筋力值にしては低くすぎる印象を受ける。

そこで本研究の目的は，HHD を用いた下腿三頭筋筋 力測定における固定ベルトを開発したので, 検者内信頼 性および検者間信頼性について調査することである。

\section{II. 対象と方法}

検者内信頼性の調查には，健常成人 11 名の両脚 22 肢 を対象とした。検者間信頼性の調査には, 健常成人 15 名 30 肢のうち, 使用するHHDの測定許容範囲（80 kg）を 超過しなかった 10 名 20 肢を対象とした（表1）。全対象 者は，腰部または下肢に障害を認めていなかった。ま た, 事前に研究の趣旨を説明し同意を得て行った。

固定ベルト（図1）は, 腰部に巻きつける腰部ベルト。

表1 対象者の内訳

\begin{tabular}{|c|c|c|c|c|c|c|}
\hline & & 例数 & 年齢（歳） & 性別 & 身長（cm） & 体重（kg） \\
\hline 検者内信頼性調査 & 11 名 & （両脚 22 脚） & $29.5 \pm 8.1$ & 男; 9 名 女; 2 名 & $167.0 \pm 7.0$ & $61.7 \pm 9.7$ \\
\hline 検者間信頼性調査 & 10 名 & (両脚 20 脚) & $24.5 \pm 5.8$ & 男; 5 名 女; 5 名 & $166.4 \pm 9.6$ & $60.5 \pm 9.8$ \\
\hline
\end{tabular}

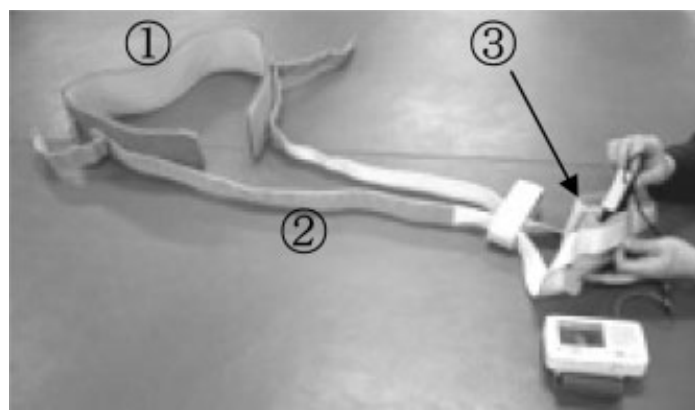

図1 下腿三頭筋筋力測定用ベルト 足部ベルトのHHD受圧部収納ポケットにHHD受圧部 を入れ込んでいる

(1) : 腰部ベルト

(2) : 腰部・足部間ベルト

(3) : 足部ベルト

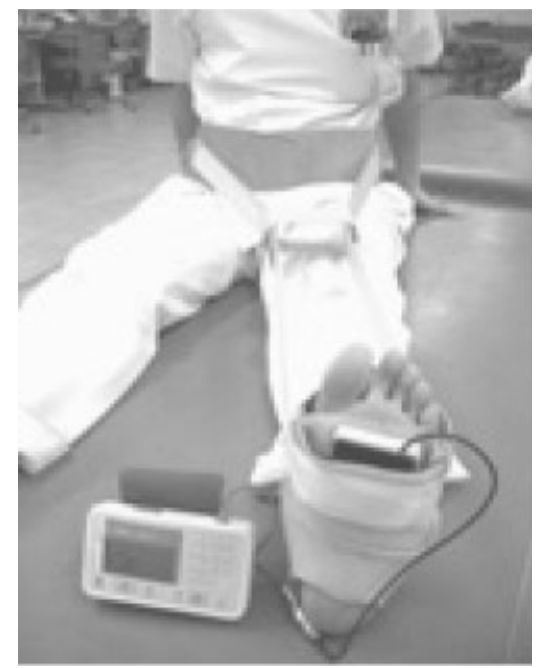

図2 下腿三頭筋筋力測定風景

腰部・足部間ベルト部分に, HHD受圧部の中 心部がくるように足部ベルトのポケットに HHD受圧部を入れ込み測定する 
腰部ベルトと足部ベルトを繋ぐベルト（腰部・足部間ベ ルト)。HHD受圧部収納ポケットが付き, 前足部を覆う ように巻きつける足部ベルトの3つのベルトより構成さ れている。各ベルトの素材は腰部ベルトが牛なめし皮, 腰部・足部間ベルトがダクロンベルト, 足部ベルトが圧 縮ウレタンネオプレーンゴムである。このうち腰部ベル トと腰部・足部間ベルトが非収縮性の性質を持ち, 足部 ベルトは異なる大きさの足部にも対応可能なように収 縮性の性質を持つ。

固定ベルトの装着方法は, (1)ジャコビー線上に腰部 のベルトを巻く, (2)足部ベルトのHHD受圧部収納ポケッ 卜部が, 中足骨底部に接地するように装着する, (3)測定 時に足関節底背屈 0 度となる程度に腰部・足部間ベルト を調節し装着した。

測定に用いたHHDは,アニマ社製 $\mu$ Tas MT-1とした。 下腿三頭筋筋力測定 (図 2) は, 長座位にて後側方に両 手を着き, 骨盤の下制や足関節内反および外反が生じな いように十分な練習後に固定ベルトを用いて等尺性足 関節底屈運動を3回測定した。

筋力測定において, 検者内信頼性調査は同一検者が, 検者間信頼性調查は二名の検者（検者 $\mathrm{A} ・ \mathrm{~B} ）$ が実施し た。検者間信頼性調查における筋力測定は，検者間でラ ンダムに測定順番を決定し, 測定間で十分な休息を設け 測定した。

信頼性の検討には, 級内相関係数 (Intraclass Correlation Coefficient；ICC）を用い5), 検者内信頼性にはICC $(1,1)$, 検者間信頼性にはICC（2,1）を用いた。

\section{III. 結 果}

検者内信頼性調査は, 筋力值が $70.2 \mathrm{~kg}$, 体重支持指数 （Weight Bearing Index ; WBI）が 115.7\%，ICC が 0.924 で

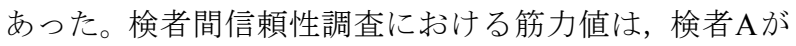
$62.2 \mathrm{~kg}$, 検者Bが $61.4 \mathrm{~kg}$ 。WBIは検者Aが $104.3 \%$, 検者 Bが102.7\%。ICCは0.809であった（表2）。

\section{IV. 考 察}

臨床上での下腿三頭筋は, 腰椎変性由来や膝関節お よび足関節周囲骨折後の局所安静による筋力低下のた めに, 青年期〜壮年期患者においても降段時の身体制御 困難や独歩での跛行などの要因になり得るために重要 である。また, 高齢者における転倒予防や平衡機能改善 において 6-8) も非常に重要な筋力の一つであり, 筋力水 準の低いものから比較的高いものまで筋力測定の重要 性は高い。しかし，下腿三頭筋の筋力測定において徒手 筋力検査は, 簡便性が高く臨床において広く普及してい る反面, 筋力の変化を客観的に捉えることに難がある。 HHD を用いた従来の筋力測定では，簡便性，価格性に 優れる反面, 信頼性に欠ける。等速度性筋力測定機器を 用いた筋力測定では, 信頼性, 客観性に優れる反面, 簡 便性，価格性に劣るために，どの測定方法も臨床での有 用性は一長一短であった。したがって, 簡便に測定可能 で価格性・信頼性・客観性に優れた下腿三頭筋筋力測定 法の確立が重要であった。

HHDを用いた従来の下腿三頭筋筋力測定方法は, MMT 「2」程度の弱化した筋力でも徒手抵抗での測定では, 抵 抗力と固定性に問題があり信頼性に欠ける。徒手抵抗に て測定するためには抵抗力と固定性を補う為に複数の 検者を要してしまうことなどの問題点を有する。しかし 今回の測定方法は, 固定ベルトを用いて抵抗・固定力を 補い，簡便性・可搬性・客観性などの HHD の特性を損 なわずに何処でも実施可能な測定方法である。さらに結 果より, 検者内信頼性がICCにて0.9以上, 検者間信頼性 が ICCにて 0.8 以上認めたことからも臨床上の使用に耐 えうる客観性・信頼性のある測定が, 誰にでも実施可能 であると考える。

最後に, 今回行った固定ベルトを用いた下腿三頭筋 筋力測定法の問題は, 腰部ベルトと腰部との適合性が十 分でないため, 䇗力測定時に腰部ベルトに若干のズレが 生じる。そのために, 足関節背屈角度やHHD 受圧部に

表2 下腿三頭筋筋力值と ICC

\begin{tabular}{|c|c|c|c|}
\hline & 筋力值（最小〜最大） & *WBI（最小〜最大） & $* *$ ICC \\
\hline 検者内信頼性調査 (n=22) & $70.2(58.7 \sim 77.1) \mathrm{kg}$ & $115.7(91.2 \sim 144.9) \%$ & 0.924 \\
\hline 検者間信頼性調查 $(n=20)$ & $\begin{array}{ll}\text { 検者 } \mathrm{A} ; 62.2 & (43.3 \sim 70.1) \mathrm{kg} \\
\text { 検者 } \mathrm{B} ; 61.4(41.1 \sim 76.4) \mathrm{kg}\end{array}$ & $\begin{array}{l}\text { 検者 } \mathrm{A} ; 104.3(84.7 \sim 123.9) \% \\
\text { 検者 } \mathrm{B} ; 102.7(84.7 \sim 129.7) \%\end{array}$ & 0.809 \\
\hline
\end{tabular}

*WBI : Weight Bearing Index（体重支持指数）：筋力值（kg）／体重（kg）～$\times 100$

**ICC : Intraclass Correlation Coefficient 
も若干のズレが生じる。よって今後は, 腰部ベルトと腰 部との適合性を高めるなどの修正が必要であると考え られる。

\section{引用文献}

1) 真田将幸, 中川法一, 森實 徹・他 : ハンドヘルドダイナモ メーターの臨床における有用性. 大阪府理学療法会誌, 2002, 30: $51-56$.

2) 杉本 諭, 小野塚直子, 篠㭚敏雄・他: ハンドヘルドダイナ モメーターを用いた足関節底屈力測定の信頼性とMMTの関 連. 理学療法学, 2005, 32: 380-383.

3) 加藤宗規:ハンドヘルドダイナモメーターによる等尺性足関 節底屈筋力の測定一固定用ベルトの使用が再現性に与える
影響一. 理学療法学, 2004, 31(Suppl): 445.

4) 西上智彦, 中尾聡志, 榎 勇人・他 : ハンドヘルドダイナモ メーターを用いた足関節底屈筋力の経日的再現性一筋力水 準の高い対象者への手法一. 高知理学療法, 2006, 13: 39-42.

5) 今井 樹, 潮見泰藏 : 理学療法研究における “評価の信頼 性” の検查法. 理学療法科学, 2004, 19 (3): 261-265.

6) Sieri T, Baretta G: Fall risk assessment in very old males and females living in nursing homes. Disabil Rehabil, 2004, 12(12): 718-723.

7) 井上和久, 植松光俊, 久保田章仁・他 : 筋力と重心動摇との 関連について。埼玉県立大学紀要, 2002, 4: 59-63.

8) 田中尚喜 : 転倒・骨折予防のための高齢者の歩行指導の有効 性と課題. CLINICAL CALCIUM, 2002, 12(4): 500-502. 